\title{
DIAGNOSIS OF PRE INVESTMENT PHASE IN HOLGUIN. A PROCESS APPROACH
}

\author{
Luis Alexis Aguilera García \\ Holguin's University Faculty of Economics and \\ Adminstration \\ University of Holguin, Holguin, Cuba \\ lagarcia@uho.edu.cu \\ Maira Rosario Moreno Pino \\ Holguin's University Faculty of Economics and \\ Adminstration \\ University of Holguin, Holguin, Cuba \\ mpino@uho.edu.cu
}

\author{
Yosvani Orlando Lao León \\ Holguin's University Faculty of Economics and \\ Adminstration \\ University of Holguin, Holguin, Cuba \\ ylaol@uho.edu.cu \\ Yumelys Lores Rodríguez \\ Specialized Security Services (SEISA) \\ Holguin, Cuba \\ yumelis@seisa.cu
}

Reception date: 12/20/2020 - Revision date: 01/19/2021 - Approval date: 01/25/2021

DOI: https://doi.org/10.36995/j.visiondefuturo.2021.25.02R.003.en

\begin{abstract}
The objective of this article is to perform a diagnostic study with a focus on preinvestment phase processes in the province of Holguín, Cuba, comparing it with other preinvestment sub-processes in Latin America. For this, methods and techniques such as Kendall's coefficient of concordance, the SWOT analysis and the House of Quality were used. The main results were the current status of the quality of the pre-investment subprocess in the Holguin context, as well as the competitive profile with respect to other preinvestment sub-processes in the region. It is concluded that the pre-investment sub-process in Holguín has as its main deficiency the low quality of the pre-investment studies, an aspect that in turn constitutes the most representative characteristic in the design of this subprocess.
\end{abstract}

KEY WORDS: Diagnosis; Investment process; Pre investment subprocess; Process approach.

\section{INTRODUCTION}

The objective of this research is to carry out a diagnosis of the pre-investment phase with a process approach in the province of Holguin, Cuba. This phase constitutes the beginning of the investment process and in turn a sub-process for the acquisition of certainty through evaluations related to the viability of the investment in question, which lead to the critical decision to invest or not. Any imprecision committed in this phase is carried over to the others, an aspect that results in a distortion, sometimes irremediable, of the initial idea of the investment and the expected results (López et al., 2012; Sáenz, 2013; Sánchez and Ledesma, 2015a; Duffus et al., 2018; Ochoa, 2019; Rodríguez, 2019).

\footnotetext{
"Visión de Futuro" Año 18, Volumen No 25 N², Julio - Diciembre 2021 - Pág 100 - 113 URL de la Revista: http://visiondefuturo.fce.unam.edu.ar/index.php/visiondefuturo/index URL del Documento: https://visiondefuturo.fce.unam.edu.ar/index.php/visiondefuturo/issue/view/21 ISSN 1668 - 8708 - Versión en Línea E-mail: revistacientifica@fce.unam.edu.ar
}

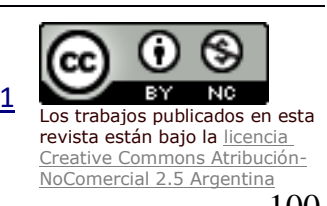


Practical experience on a global scale indicates that it is not enough to have sufficient resources to achieve the objectives of an investment project, but that the quality of the analysis and studies carried out in the pre-investment phase, and the quality in the execution of these in the later phases; since this phase constitutes the structural basis of the process and a turning point for the diagnosis of the process in general (Secretariat of Planning and Programming of the Presidency in Guatemala, 2002; Thompson, 2009; Apaza, 2015; Colombian Chamber of Infrastructure , 2016).

In the province of Holguin, important investment processes are currently being developed in strategic sectors such as tourism, health and agriculture. The dynamism and interconnections of these investment projects demand a more efficient and competitive structure of the pre-investment phase as an elementary sub-process, based on a timely diagnosis of it. Despite the aforementioned elements, it is not a common practice in Holguin organizations to diagnose the pre-investment phase as a key sub-process of the investment process in general, nor as a tool to identify errors and deviations, as well as opportunities for improvement. , an aspect that has sometimes compromised important and scarce resources in failed investment processes. This situation is evident in the coexistence of deficiencies in the development of this phase. These can be grouped into:

\section{Technical quality of pre-investment studies}

- Feasibility studies with low rigor and depth level (Valarezo et al., 2016);

- There are no common quality standards for the pre-investment phase that function as essential requirements for the successful development of this phase (Ochoa, 2019; Rodríguez, 2019; Aguilera et al., 2020);

- The existing gaps in the evaluation of the studies carried out in the pre-investment phase causes the acceptance of superficial market studies without a correct quantification and argumentation of the identified demand (s) (Duffus et al., 2018);

- Inadequate procedures for calculating depreciation that lead to errors in the estimation of taxes, replacements and residual values, resulting in results with a greater margin of error than planned (Sáenz, 2013).

\section{Reliability of the results}

- Dispersion of the information necessary to carry out the analyzes and forecasts, an aspect that leads to greater imprecision in the final evaluation contained in these studies (Sánchez et al., 2015a);

\footnotetext{
"Visión de Futuro" Año 18, Volumen $\mathrm{N}^{\circ} 25$ No 2, Julio - Diciembre 2021 - Pág 100 - 113

URL de la Revista: http://visiondefuturo.fce.unam.edu.ar/index.php/visiondefuturo/index

URL del Documento: https://visiondefuturo.fce.unam.edu.ar/index.php/visiondefuturo/issue/view/21

ISSN 1668 - 8708 - Versión en Línea

E-mail: $\underline{\text { revistacientifica@fce.unam.edu.ar }}$
} 
- The failure to carry out comprehensive evaluations of the studies and analyzes carried out in the pre-investment phase makes it difficult to analyze the reliability of the resulting information (Sánchez and Ledesma, 2018);

- The non-existence of branch coefficients makes the correct application of the discount rate difficult, an aspect that distorts the viability of the investment, and sometimes, its final result (Martín and Leyva, 2017);

\section{Schedules deviations}

- The weak compliance with the schedules causes important lags in the pre-investment phase that threaten the correct execution of the budget and the quality of the phase in general (Sánchez and Ledesma, 2015b);

- The delays in the delivery of the technical documentation for the preparation of the preinvestment studies, influences the dilation of the pre-investment phase;

- The management of the investment process sometimes lacks a comprehensive approach that involves all stakeholders in the synchronization of activities and their compliance (Sardiñas, 2016).

Therefore, it is necessary to focus on processes in the diagnosis of the pre-investment phase for the identification of opportunities for improvement and eradication in time, of deviations in the expected results, in the Holguin context. These elements contribute to achieving a higher quality thread.

\section{DEVELOPMENT}

\section{1.- Background}

Decisions related to investment processes include analyzes and projections of the rational, present and future use of material, human and financial resources, to obtain profits, from a sustainable social, economic and environmental perspective (Peña et al., 2015). Each phase of the process constitutes a sub-process of the process and contributes to the fulfillment of the objectives that motivated the investment (Paño, 2016). Although all phases are important, the pre-investment phase, as the initial link in the process and as an essential source of information for the following phases, constitutes a backbone in the success of the investment project (Thompson, 2009; Sapag, 2011; Vera, 2015; Cabrera and Paredes, 2016; Villafuerte, 2016; Wang et al., 2018; Aguilera et al., 2020).

Any inaccuracy committed in this phase generally has an irreversible character, being

\footnotetext{
"Visión de Futuro" Año 18, Volumen No 25 N 2, Julio - Diciembre 2021 - Pág 100 - 113

URL de la Revista: http://visiondefuturo.fce.unam.edu.ar/index.php/visiondefuturo/index

URL del Documento: https://visiondefuturo.fce.unam.edu.ar/index.php/visiondefuturo/issue/view/21

ISSN 1668 - 8708 - Versión en Línea

E-mail: revistacientifica@fce.unam.edu.ar
} 
reflected in the rest of the phases (sub-processes) when its effects are practically inevitable (López et al., 2012; Sáenz, 2013; Sánchez et al., 2015a; Duffus et al. al., 2018; Ochoa, 2019; Rodríguez, 2019), therefore, its analysis from the process approach is relevant. In the literature consulted, various authors refer that the use of conventional business management tools such as SWOT analysis (Olivera and Matamoros, 2011; Foschiatti and Alberto, 2012) and the House of Quality or QFD (Quality Function Deployment) is appropriate (Shen et al., 2001; Reich and Levy, 2004; Kim et al., 2007) for the analysis and design of processes respectively (Sarmiento et al., 2004; Kim et al., 2007; Elizondo, 2019). However, in the bibliographic sources that were accessed, the use of the process approach in the diagnosis of the investment process, and specifically of the pre-investment phase, is not verified, but they tend to be analyzed merely from economic indicators.

\section{2.- Materials y methods}

In the development of the research, the Kendall's concordance coefficient method with a descending weighting scale was used to evaluate the consensus of the experts and the resolution of contradictions that affect the problem and seek theoretical-practical solutions that contribute to the solution to this problem. The SWOT matrix was used for the diagnosis of the pre-investment phase in the Holguin context and the House of Quality (QFD) for the identification of improvement opportunities that contribute to the quality and assertiveness of the process. Other theoretical methods such as: analysis and synthesis, inductive-deductive and the structural systemic were used for the analysis of the documentary references in the specialized literature associated with the investment process and the pre-investment phase.

\section{3.- Selection of the expert group}

For the diagnosis of the pre-investment phase in the province of Holguín, nine experts were selected, three doctors in technical sciences, four doctors in economic sciences and two investors from the business sector in operation. The work history and experience of each expert in their field was taken into account, as well as their direct and indirect relationship with the investment process. The experts are grouped into three work centers: seven from the University of Holguín, one from the Provincial Government and one from the National Association of Economists of Cuba.

\section{4.- Data collecting}

To identify the main strengths, weaknesses, threats, and opportunities of the pre-

\footnotetext{
"Visión de Futuro" Año 18, Volumen No 25 N², Julio - Diciembre 2021 - Pág 100 - 113

URL de la Revista: http://visiondefuturo.fce.unam.edu.ar/index.php/visiondefuturo/index

URL del Documento: https://visiondefuturo.fce.unam.edu.ar/index.php/visiondefuturo/issue/view/21

ISSN 1668 - 8708 - Versión en Línea

E-mail: revistacientifica@fce.unam.edu.ar
} 
investment phase in Holguin, the selected experts were consulted through the application of an instrument (figure 1). This was validated through Cronbach's alpha coefficient, obtaining a value of $\alpha=0.76$, therefore, the survey is reliable. The Kendall's coefficient of agreement method was used to assess the level of consensus between them.

\section{QUESTIONNAIRE}

Dear collaborator, we would like to collect your considerations regarding the investment process in order to identify and weigh the main strengths $(F)$-weaknesses $(D)$ and opportunities $(O)$-threats $(A)$ that are most representative of the pre-investment phase in Holguin province.

We appreciate your collaboration in answering this questionnaire and the effort to report the data with high reliability. The results obtained from its application will be handled with complete confidentiality since the study is strictly academic.

Instructions: read the entire document carefully and list the F, D, O and A and ponder from your consideration of the extent to which they impact on the development of the pre-investment phase in Holguín province (1. Very weak 2. Weak 3. Medium 4. Strong 5. Very strong)

Strengthening the University-Company relationship (F)

Increase in the volume of investment processes in the province of Holguín in strategic sectors (F)

Greater autonomy granted to provincial governments by the State with respect to the management of investment processes from the initial phase (pre-investment) (F)

Development of intersectoral projects such as the East-West Transfer and the Ramón de Antilla Tourist Center (F)

Enhancement of consulting services in conducting pre-investment studies $(F)$

Breach of established schedules and deadlines (D)

Excess of bureaucratic procedures to specify investment opportunities (D)

Gaps in the training process in the personnel participating in the pre-investment studies (D)

Deficiencies in the management of the information inherent to the pre-investment phase (D)

Dispersion, shallow depth and low rigor in pre-investment studies (D)

Change in the country's energy matrix, an aspect that influences the development of renewable energy projects in the province of Holguín $(\mathrm{O})$

Orientation of the State policy towards the successful development of the investment process and within this the pre-investment phase $(\mathrm{O})$

The globalization of professional services allows the fruitful exchange of experiences regarding the investment process and the execution of the pre-investment phase $(O)$

$\begin{array}{lllll}1 & 2 & 3 & 4 & 5 \\ 1 & 2 & 3 & 4 & 5 \\ 1 & 2 & 3 & 4 & 5 \\ 1 & 2 & 3 & 4 & 5 \\ 1 & 2 & 3 & 4 & 5 \\ 1 & 2 & 3 & 4 & 5 \\ 1 & 2 & 3 & 4 & 5 \\ 1 & 2 & 3 & 4 & 5 \\ 1 & 2 & 3 & 4 & 5 \\ 1 & 2 & 3 & 4 & 5 \\ 1 & 2 & 3 & 4 & 5 \\ 1 & 2 & 3 & 4 & 5 \\ 1 & 2 & 3 & 4 & 5\end{array}$

\footnotetext{
"Visión de Futuro" Año 18, Volumen $N^{\circ} 25$ № 2, Julio - Diciembre 2021 - Pág 100 - 113

URL de la Revista: http://visiondefuturo.fce.unam.edu.ar/index.php/visiondefuturo/index

URL del Documento: https://visiondefuturo.fce.unam.edu.ar/index.php/visiondefuturo/issue/view/21

ISSN 1668 - 8708 - Versión en Línea

E-mail: revistacientifica@fce.unam.edu.ar
} 
The potentiality of foreign investment in the territory presupposes a greater preparation of investors in terms of engineering studies as well as technical-economic pre and feasibility $(\mathrm{O})$

Conducting scientific and empirical research on the performance of the preinvestment phase $(\mathrm{O})$

Increase in the economic blockade of the United States against Cuba (A)

Global health-economic crisis (A)

Instability in the supply chain (A)

Monetary duality $(\mathrm{A})$

Limitations in the country's construction capacity $(A)$

$\begin{array}{lllll}1 & 2 & 3 & 4 & 5 \\ 1 & 2 & 3 & 4 & 5 \\ 1 & 2 & 3 & 4 & 5 \\ 1 & 2 & 3 & 4 & 5 \\ 1 & 2 & 3 & 4 & 5 \\ 1 & 2 & 3 & 4 & 5 \\ 1 & 2 & 3 & 4 & 5\end{array}$

Figure № 1: Sourvey to identify the factors that affect the pre investment phase execution in Holguin.

Source: Own elaboration

For this, a descending weighting scale (1-10) was used, a Kendall's concordance coefficient of 0.97 was obtained, therefore there was consensus in the criterion of the group of experts, this was validated from the corresponding non-parametric test (chi -square), where the calculated statistic (20.64) was greater than the tabulated one (7.86). The experts agree that the strengths-weaknesses and opportunities-threats as well as their weighting are those listed in table $1 \& 2$.

Table №1: Weighting of internal factors

\begin{tabular}{|c|c|c|}
\hline Strengths & In & W \\
\hline Strengthening the University-Company relationship & S1 & 3 \\
\hline Increase in the volume of investment processes in the province of Holguín in strategic sectors & S2 & 3 \\
\hline $\begin{array}{c}\text { Greater autonomy granted to provincial governments by the State with respect to the management of } \\
\text { investment processes from the initial phase (pre-investment) }\end{array}$ & S3 & 4 \\
\hline $\begin{array}{c}\text { Development of intersectoral projects such as the East-West Transfer and the Ramón de Antilla Tourist } \\
\text { Center }\end{array}$ & S4 & 4 \\
\hline Enhancement of consulting services in conducting pre-investment studies & S5 & 4 \\
\hline \multicolumn{3}{|l|}{ Weaknesses } \\
\hline Breach of established schedules and deadlines & Wk1 & 1 \\
\hline Excess of bureaucratic procedures to specify investment opportunities & Wk2 & 2 \\
\hline Gaps in the training process in the personnel involved in conducting pre-investment studies & Wk3 & 1 \\
\hline Deficiencies in the management of the information inherent in the pre-investment phase & Wk4 & 1 \\
\hline Dispersion, shallow depth and low rigor in pre-investment studies & Wk5 & \\
\hline
\end{tabular}

Source: Own elaboration

\footnotetext{
"Visión de Futuro" Año 18, Volumen No 25 N 2, Julio - Diciembre 2021 - Pág 100 - 113

URL de la Revista: http://visiondefuturo.fce.unam.edu.ar/index.php/visiondefuturo/index

URL del Documento: https://visiondefuturo.fce.unam.edu.ar/index.php/visiondefuturo/issue/view/21

ISSN 1668 - 8708 - Versión en Línea

E-mail: revistacientifica@fce.unam.edu.ar
} 
Table №2: Weighting of external factors

\begin{tabular}{|c|c|c|}
\hline Oportunities & In & W \\
\hline $\begin{array}{l}\text { Change in the country's energy matrix, an aspect that influences the development of } \\
\text { renewable energy projects in the province of Holguín }\end{array}$ & O1 & 3 \\
\hline $\begin{array}{c}\text { Orientation of the State policy towards the successful development of the investment } \\
\text { process and within this the pre-investment phase }\end{array}$ & $\mathrm{O} 2$ & 4 \\
\hline $\begin{array}{l}\text { The globalization of professional services allows the fruitful exchange of experiences } \\
\text { regarding the investment process and the execution of the pre-investment phase }\end{array}$ & $\mathrm{O} 3$ & 3 \\
\hline $\begin{array}{l}\text { The potentiality of foreign investment in the territory presupposes a greater preparation of } \\
\text { investors in terms of engineering studies as well as technical-economic pre and feasibility }\end{array}$ & $\mathrm{O} 4$ & 4 \\
\hline $\begin{array}{c}\text { Conducting scientific and empirical research on the performance of the pre-investment } \\
\text { phase }\end{array}$ & O5 & 4 \\
\hline Threats & $\mathrm{Sg}$ & $\mathbf{P}$ \\
\hline Recruciating of the economic blockade of the United States against Cuba & $\mathrm{T1}$ & 1 \\
\hline Global health-economic crisis & T2 & 1 \\
\hline Instability in the supply chain & T3 & 2 \\
\hline Monetary duality & T4 & 1 \\
\hline Limitations in the country's constructive capacity & T5 & 2 \\
\hline
\end{tabular}

Source: Own elaboration

\section{5.- Data analysis}

The weightings of the factors were processed in the SWOT Matrix software, the results of the analysis being reflected in Figure 2. It can be seen that for the pre-investment phase in Holguín a matrix value of 34.5 was obtained, being in quadrant II, zone of protection, having to adopt defensive strategies that maximize current strengths and minimize the effect of threats from the environment.

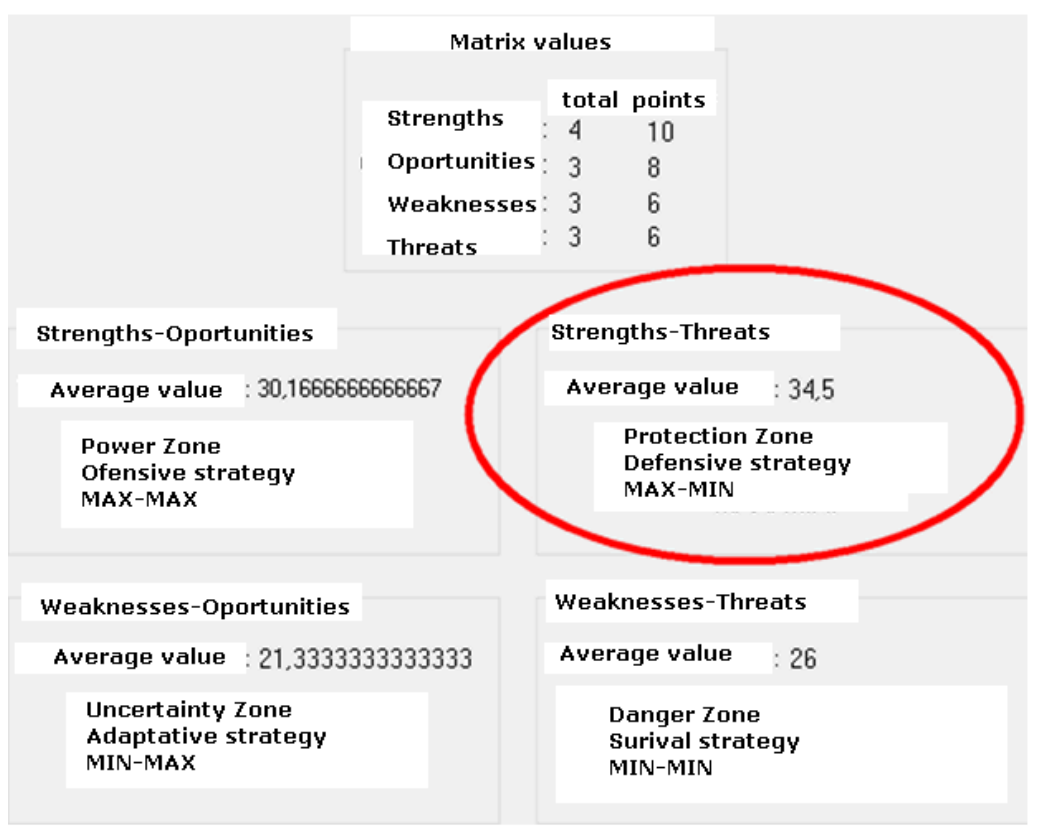

Figure №2: SWOT analysis results

Source: SWOT Matrix Software

\footnotetext{
"Visión de Futuro" Año 18, Volumen No 25 N², Julio - Diciembre 2021 - Pág 100 - 113

URL de la Revista: http://visiondefuturo.fce.unam.edu.ar/index.php/visiondefuturo/index

URL del Documento: https://visiondefuturo.fce.unam.edu.ar/index.php/visiondefuturo/issue/view/21

ISSN 1668 - 8708 - Versión en Línea

E-mail: revistacientifica@fce.unam.edu.ar
} 
Consequently, to enhance the current strengths and counteract the effect of the identified threats, a pre-investment sub-process design is proposed in Holguín, which contributes to a higher quality and assertiveness of the same. For this, the House of Quality or Deployment of the Quality Function (QFD) was used, since it contemplates the translation of external requirements to the process / good / service to internal technical characteristics necessary in the execution / production of the process / good / service.

It also constitutes a formal mechanism to ensure that the client's needs, expressed in their own terms (the voice of the client), are translated into technical language.

For the application of this tool, the following work scheme was developed:

1. Determine customer requirements (actual characteristics).

2. Weight the actual characteristics.

3. Identify surrogate characteristics. The characteristics of the process indicated by the client (investors, designers, builders) must be transformed into technical requirements (design requirements equivalent to the substitute characteristics) that exert a direct influence on the perceptions of the client.

4. Develop the central relationship matrix between customer requirements and surrogate characteristics. This indicates the degree to which each of the surrogate characteristics affects the characteristics indicated by the client.

5. Prepare the Superior or Triangular Relationship Matrix (correlation between the surrogate characteristics). It allows making changes between steps 3 and 4 in order to judge the possible pros and cons between the surrogate characteristics and those pointed out by the customer.

6. Determine the competitive evaluation. The competitive profile of the pre-investment subprocess is obtained in the Holguin context.

Together with the group of experts, a survey was carried out of the main proposals of the different organizations immersed in investment processes in the province and that act as direct investors, planners, builders and other subjects of the investment process (Council of Ministers, 2015), which were taken as real characteristics. A second survey $(\alpha=0.81)$ was applied and validated to the group of experts for the weighting of the real characteristics and their respective translation into the technical language inherent to the investment process and the pre-investment phase in Holguin (table 3) as well as, for classify the relationship between real and substitute characteristics as: strong, medium and weak reflected in figure 3.

\footnotetext{
"Visión de Futuro" Año 18, Volumen No 25 N 2, Julio - Diciembre 2021 - Pág 100 - 113

URL de la Revista: http://visiondefuturo.fce.unam.edu.ar/index.php/visiondefuturo/index

URL del Documento: https://visiondefuturo.fce.unam.edu.ar/index.php/visiondefuturo/issue/view/21

ISSN 1668 - 8708 - Versión en Línea

E-mail: revistacientifica@fce.unam.edu.ar
} 
Table №3: Real characteristics translation

\begin{tabular}{|c|c|c|c|}
\hline In & User requirements & W & Surrogate characteristics \\
\hline $\begin{array}{l}\text { A } \\
\text { B }\end{array}$ & $\begin{array}{l}\text { Timely pre-investment studies } \\
\text { Correct use of feasibility studies }\end{array}$ & $\begin{array}{l}5 \\
4\end{array}$ & $\begin{array}{l}\text { 1) Quality of pre-investment studies (A, B) } \\
\text { 2) Speeding up investment approval (C) }\end{array}$ \\
\hline C & Unblock bureaucratic obstacles & 3 & 3) High qualification of work teams (D) \\
\hline $\begin{array}{l}\mathrm{D} \\
\mathrm{E}\end{array}$ & $\begin{array}{l}\text { Staff with investment training } \\
\text { Sustained investment growth }\end{array}$ & $\begin{array}{l}5 \\
5\end{array}$ & $\begin{array}{l}\text { 4) Investment rate increase (E) } \\
\text { 5) Correct planning and control of the investment } \\
\text { (s) schedules (F) }\end{array}$ \\
\hline $\begin{array}{l}\mathbf{F} \\
\mathbf{G}\end{array}$ & $\begin{array}{l}\text { Discipline in compliance with investment plans } \\
\text { Facilitate access to updated information }\end{array}$ & $\begin{array}{l}5 \\
4\end{array}$ & $\begin{array}{l}\text { 6) Efficient information management }(\mathrm{G}, \mathrm{J}) \\
\text { 7) Organization of constructive capacities }(\mathrm{H})\end{array}$ \\
\hline $\begin{array}{l}\mathbf{H} \\
\mathbf{I}\end{array}$ & Increase in building forces & $\begin{array}{l}5 \\
4\end{array}$ & $\begin{array}{l}\text { (I) } \\
\text {-Invent pnase activities }\end{array}$ \\
\hline $\mathbf{J}$ & Simultaneous tasks & 4 & \\
\hline
\end{tabular}

Source: Expert judgments 


\section{QUESTIONNAIRE}

Dear collaborator, we would like to collect your considerations to weigh the real characteristics of the pre-investment phase of the investment process and identify the relationship between these and the technical or substitute characteristics.

We appreciate your collaboration in answering this questionnaire and the effort to report the data with high reliability. The results obtained from its application will be handled with complete confidentiality since the study is strictly academic.

Instructions: read the entire document carefully, weigh the real characteristics according to the importance given to it within the investment process (1. Very low importance 2. Low importance 3. Medium importance 4. High importance 5. Extreme importance)

Then:

Rate the relationship between real and surrogate characteristics (1. Strong. 2. Medium. 3. Weak)

\begin{tabular}{|c|c|c|c|c|c|c|c|}
\hline Real characteristic & Technical feature & Relation & 1 & 2 & 3 & 4 & 5 \\
\hline Reliable pre-investment studies & \multirow{2}{*}{$\begin{array}{l}\text { Quality of pre } \\
\text { investment studies }\end{array}$} & & & & & & \\
\hline $\begin{array}{l}\text { Correct performance of } \\
\text { feasibility studies }\end{array}$ & & & & & & & \\
\hline Unblock bureaucratic obstacles & $\begin{array}{c}\text { Speeding up investment } \\
\text { approval }\end{array}$ & & & & & & \\
\hline Staff with investment training & $\begin{array}{l}\text { High qualification of } \\
\text { work teams }\end{array}$ & & & & & & \\
\hline Sustained investment growth & Investment rate increase & & & & & & \\
\hline $\begin{array}{l}\text { Discipline in compliance with } \\
\text { investment plans }\end{array}$ & $\begin{array}{l}\text { Correct planning and } \\
\text { control of the investment } \\
\text { (s) schedules }\end{array}$ & & & & & & \\
\hline $\begin{array}{l}\text { Facilitate access to updated } \\
\text { information }\end{array}$ & $\begin{array}{l}\text { Efficient information } \\
\text { management }\end{array}$ & & & & & & \\
\hline Increase in building forces & $\begin{array}{c}\text { Organization of } \\
\text { constructive capacities }\end{array}$ & & & & & & \\
\hline Simultaneous tasks & $\begin{array}{l}\text { Streamlining of } \\
\text { pre-investment phase } \\
\text { activities }\end{array}$ & & & & & & \\
\hline $\begin{array}{c}\text { Periodically update economic } \\
\text { information in statistical } \\
\text { yearbooks }\end{array}$ & $\begin{array}{l}\text { Efficient information } \\
\text { management }\end{array}$ & & & & & & \\
\hline
\end{tabular}

Figure № 3: Sourvey about level of importance and type of relationship between real and technical characteristics.

Source: Own elaboration

A selection of countries in the region was made, taking into account the dynamism in investments and their sustained growth, since the performance of the pre-investment phase within the investment processes of Brazil was taken into account for the competition analysis. , Colombia and Panama (ECLAC, 2019). For the competitive evaluation, the behavior of the aforementioned real characteristics in these countries was taken into account and they were rated on an ascending scale (1-5) by the experts based on the analysis of the behavior of the following criteria (ECLAC, 2019):

- Total investment volume

\footnotetext{
“Visión de Futuro" Año 18, Volumen $\mathrm{N}^{\circ} 25$ No 2, Julio - Diciembre 2021 - Pág 100 - 113

URL de la Revista: http://visiondefuturo.fce.unam.edu.ar/index.php/visiondefuturo/index

URL del Documento: https://visiondefuturo.fce.unam.edu.ar/index.php/visiondefuturo/issue/view/21

ISSN 1668 - 8708 - Versión en Línea

E-mail: $\underline{\text { revistacientifica@fce.unam.edu.ar }}$
} 
- GDP growth from investments

- National development plans and their scope

- Legal provisions, procedures and quality standards regarding the pre-investment phase

- It should be noted that although Holguin represents a province, the competitive evaluation considered countries based on the degree of interconnections between the provinces of these countries and their respective National Public Investment Systems.

\section{6.- Results}

By displaying the quality function, it was observed that the technical characteristics (upper central part, figure 4) with the highest score (lower central part, figure 4) were the quality of the pre-investment studies, the high qualification of the work teams, the correct planning and control of investment schedules and efficient information management. Therefore, these constitute the main quality characteristics of the pre-investment subprocess.

LEGEND

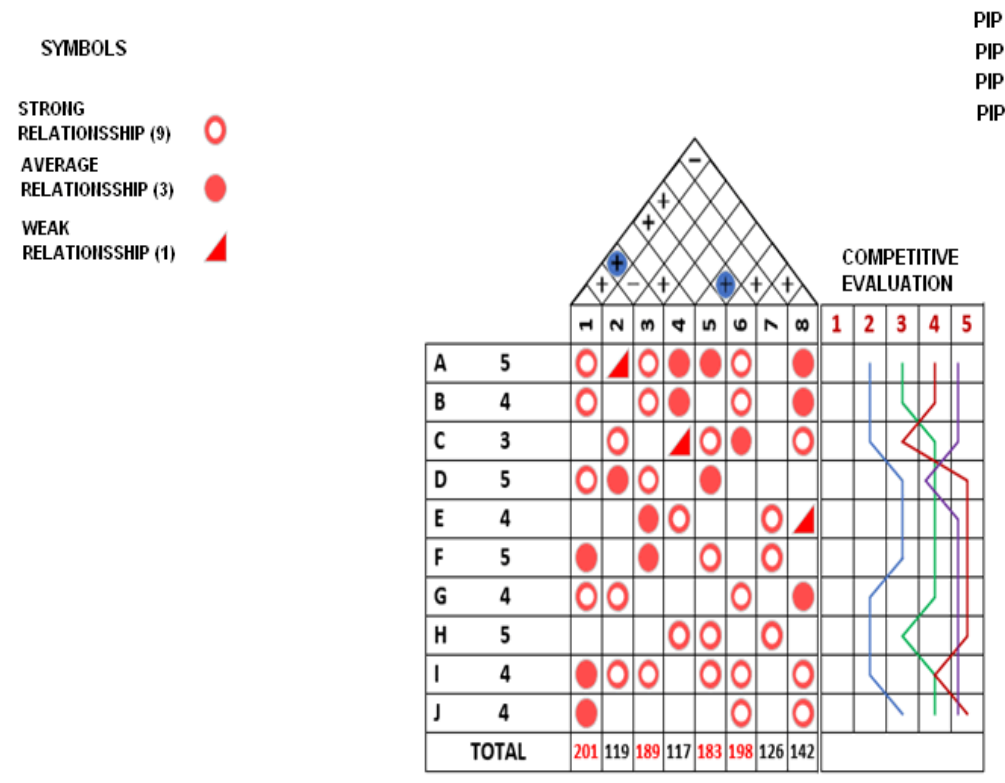

Figure № 4: House of Quality applied to the pre-investment phase in Holguin Source: Own elaboration

\footnotetext{
"Visión de Futuro" Año 18, Volumen No 25 N², Julio - Diciembre 2021 - Pág 100 - 113 URL de la Revista: http://visiondefuturo.fce.unam.edu.ar/index.php/visiondefuturo/index URL del Documento: https://visiondefuturo.fce.unam.edu.ar/index.php/visiondefuturo/issue/view/21 ISSN 1668 - 8708 - Versión en Línea 
The competitive profile of the pre-investment phase in the investment processes of Brazil, Colombia and Panama was analyzed, resulting in the profile of Brazil being the most solid in the area (right side Figure 4). A comparison was made of the profile of Brazil with that of the province of Holguín, obtaining the weakest points of the pre-investment phase. Deficiencies in conducting pre-investment studies, bureaucratic obstacles, access to up-todate information and the impossibility of simultaneous tasks represent the weakest points of the PIP in Holguin.

On the other hand, there are potential for improvement in the preparation of work teams, the sustained growth of investments and in the fulfillment of investment plans and schedules. It is necessary to underline the link of the weakest points and the opportunities for improvement with the most important quality characteristics. Therefore, considering the latter as requirements for the design of the pre-investment sub-process in Holguín constitutes an objective way of minimizing the effect of the weaknesses detected for a better use of the opportunities identified in the competitive profile of the PIP in Holguin.

\section{7.- Proposal of variables to consider in the redesign of the pre-investment process in}

\section{Holguin}

The quality of pre-investment studies represents an essential factor to achieve the success of the investment (Aguilera García et al., 2020). The correct argumentation of the demand and the depreciation in the market studies, the timely estimation of the working capital and the realization of the pre and economic technical feasibility studies with the required depth contribute to the achievement of the quality and the success of this phase and therefore of the process in general. Therefore, the evaluation of the quality with which the pre-investment phase is developed is proposed as part of the design of the process, being a strategic element that provides assertiveness to it.

On the other hand, the preparation and qualification of the work teams immersed in the execution of the PIP in Holguin constitutes a necessary condition to guarantee the assertiveness of this sub-process (Sánchez et al., 2018). Therefore, specific training actions should be intended for these work groups oriented to technical, economic and quality aspects inherent to the studies and analyzes carried out in the aforementioned sub-process. Furthermore, the process approach in the management of the PIP is consistent, taking into account that its main output is the information to be used in the rest of the sub-processes (execution-exploitation and deactivation) that make up the investment process.

Another important element to consider in the design of the pre-investment sub-process

\footnotetext{
"Visión de Futuro" Año 18, Volumen No 25 N² 2, Julio - Diciembre 2021 - Pág 100 - 113

URL de la Revista: http://visiondefuturo.fce.unam.edu.ar/index.php/visiondefuturo/index

URL del Documento: https://visiondefuturo.fce.unam.edu.ar/index.php/visiondefuturo/issue/view/21

ISSN 1668 - 8708 - Versión en Línea

E-mail: revistacientifica@fce.unam.edu.ar
} 
in the Holguin context is compliance with the deadlines or schedules, an aspect that has significant specific weight in the successful development of the pre-investment phase and the investment process in general (Garro , 2015). Its role in controlling investment development in an integral way influences the efficiency of the sub-process (Mahlotra, 2004; López and García, 2012; Mesa, 2012; Valarezo et al., 2016; Martín et al., 2017; Almarales et al. al., 2019).

Strict compliance with the schedules must be supported by an effective simultaneity of tasks in each of the activities of the pre-investment sub-process. Although the simultaneity of tasks does not represent a schematic way to streamline and ensure compliance with deadlines, it must be legally supported as the backbone of the sub-process, taking into account the specificity of each investment project and its characteristics.

Por tanto, generalizar el empleo de herramientas de temporización y planificación como el Enfoque Marco-Lógico (Sánchez, 2007; Sainz et al., 2015; Monroy, 2018), método CPM (Lao, 2013) y el diagrama de Gantt (Honores, 2017), constituye un punto de inflexión para el logro de una mejor planificación, ejecución y control de los cronogramas desde el subproceso pre inversión.

Therefore, generalize the use of timing and planning tools such as the FrameworkLogical Approach (Sánchez, 2007; Sainz et al., 2015; Monroy, 2018), CPM method (Lao, 2013) and the Gantt chart (Honores, 2017), constitutes a turning point for achieving better planning, execution and control of schedules from the pre-investment sub-process.

However, the aforementioned elements must be supported by an optimal management of the information that mainstreams all the activities of the pre-investment sub-process. The updating of the main statistical yearbooks and the accessibility to real market data constitute emerging measures to achieve greater reliability in the analyzes and forecasts carried out in the pre-investment phase.

\section{CONCLUSION}

The pre-investment sub-process in Holguín is located in the protection quadrant, having to adopt defensive strategies aimed at enhancing strengths to mitigate external threats.

The most representative quality characteristics in the design of the pre-investment subprocess in Holguín are: the quality of the pre-investment studies, the high qualification of the work teams immersed in the sub-process, the correct planning and control of the investment schedules. and efficient information management.

\footnotetext{
"Visión de Futuro" Año 18, Volumen No 25 No 2, Julio - Diciembre 2021 - Pág 100 - 113

URL de la Revista: http://visiondefuturo.fce.unam.edu.ar/index.php/visiondefuturo/index

URL del Documento: https://visiondefuturo.fce.unam.edu.ar/index.php/visiondefuturo/issue/view/21

ISSN 1668 - 8708 - Versión en Línea

E-mail: revistacientifica@fce.unam.edu.ar
} 
The pre-investment sub-process in Holguín presents as weak points within its competitive profile the deficiencies in the timely performance of pre-investment studies, obstacles in accessing up-to-date information to carry out pre-investment studies and gaps in the simultaneous performance of tasks that favor agility in the execution of the preinvestment phase.

The opportunities to improve the pre-investment sub-process in the Holguin context, according to its competitive profile, are associated with a better preparation of the work teams, the sustained growth of the investments and the fulfillment of the investment plans and schedules.

The weak points and opportunities for improvement of the pre-investment sub-process in Holguín are linked to the most significant quality characteristics and represent requirements for the design of the sub-process.

The proposed design of the pre-investment sub-process in the Holguin context considers the quality characteristics most valued by clients, the weaknesses and the opportunities for improvement, as it contributes to the quality and assertiveness of the preinvestment phase in Holguin.

\section{REFERENCES}

Please refer to articles in Spanish Bibliography.

\section{BIBLIOGRAPHICAL ABSTRACT}

Please refer to articles Spanish Biographical abstract.

\footnotetext{
"Visión de Futuro" Año 18, Volumen No 25 ํo 2, Julio - Diciembre 2021 - Pág 100 - 113

URL de la Revista: http://visiondefuturo.fce.unam.edu.ar/index.php/visiondefuturo/index

URL del Documento: https://visiondefuturo.fce.unam.edu.ar/index.php/visiondefuturo/issue/view/21

ISSN 1668 - 8708 - Versión en Línea

E-mail: revistacientifica@fce.unam.edu.ar
} 